\title{
Function Design of Township Enterprise Online Approval System
}

\author{
Peng $\mathrm{Lu}^{1}$, Gang $\mathrm{Lu}^{2}$, and Chao Ding ${ }^{2}$ \\ ${ }^{1}$ Tourism Department, Hebei Normal University, Shijiazhuang, Hebei, China \\ ${ }^{2}$ School of Management and Engineering, Shijiazhuang University of Economics, \\ Shijiazhuang, Hebei, China \\ lpzzl1h@126.com, 1031@163.com, dingchao@sjzue.edu.cn
}

\begin{abstract}
Township enterprise is a kind of new economic organization that appeared under the special historical background in rural areas of China. Since 30 years of reform and opening-up, township enterprise has made a great contribution to the economic development of China with its unique development style and great vitality. Taking the place of the traditional manual way, township enterprise online approval system applies computer and network technology to realize the normalization and standardization of approval and administration of township enterprise. This paper first gives an introduction on the comprehensive function design of township enterprise online approval system, then makes an evaluation on the system, last points out the sphere of application of this system.
\end{abstract}

Keywords: Township Enterprise; Online Approval System; Evaluation; Sphere of Application.

Since 1990s, human being entered into the Information-Dominated society, which is also called information society. According to the requirements of avoiding risk, moderate advancement and market operation, the management department of township enterprises should provide general business information services and agricultural enterprise information application services for characteristic industry, such as shoemaking, textile and garment, stone carving and stone processing, petrochemical industry, pottery and porcelain, hardware and electromechanical, tea, orange and so on. The agricultural enterprise application service system can provide township enterprises with integrated services in improving production efficiency, reducing cost and timely information gathering. At the same time, we should encourage the powerful and reputable information product enterprises to provide the peasants with both information services and business information in supplying and selling agricultural products. We should also strengthen supervision and crack down on price deception and the behavior of selling shoddy terminals so as to protect the legitimate interests of peasants. Therefore, we should build a government-dominating informationalized township enterprise constructing and organizing management institution and make an overall and long-term general plan for information development and a series of township enterprise e-business normative system to ensure the verity and health of the township enterprise information and the smooth channels of information collecting and 
communicating and to strengthen the macro- guidance to the development of township enterprise e-business.

\section{The Introduction of Township Enterprise Online Approval System}

The township enterprise business online approval system can achieve the standardization of township enterprise approval by using the computer and network technology instead of the traditional manual way to handle the application and approval of township enterprise. The administrative department of township enterprise acts as trade and economy commission in the villages and towns, as township enterprise administrative bureau or industrial promotion bureau in the county and also as a small-and-middle-sized enterprise bureau affiliated to industrial information office in the province. The responsibilities of the superior management departments are mainly

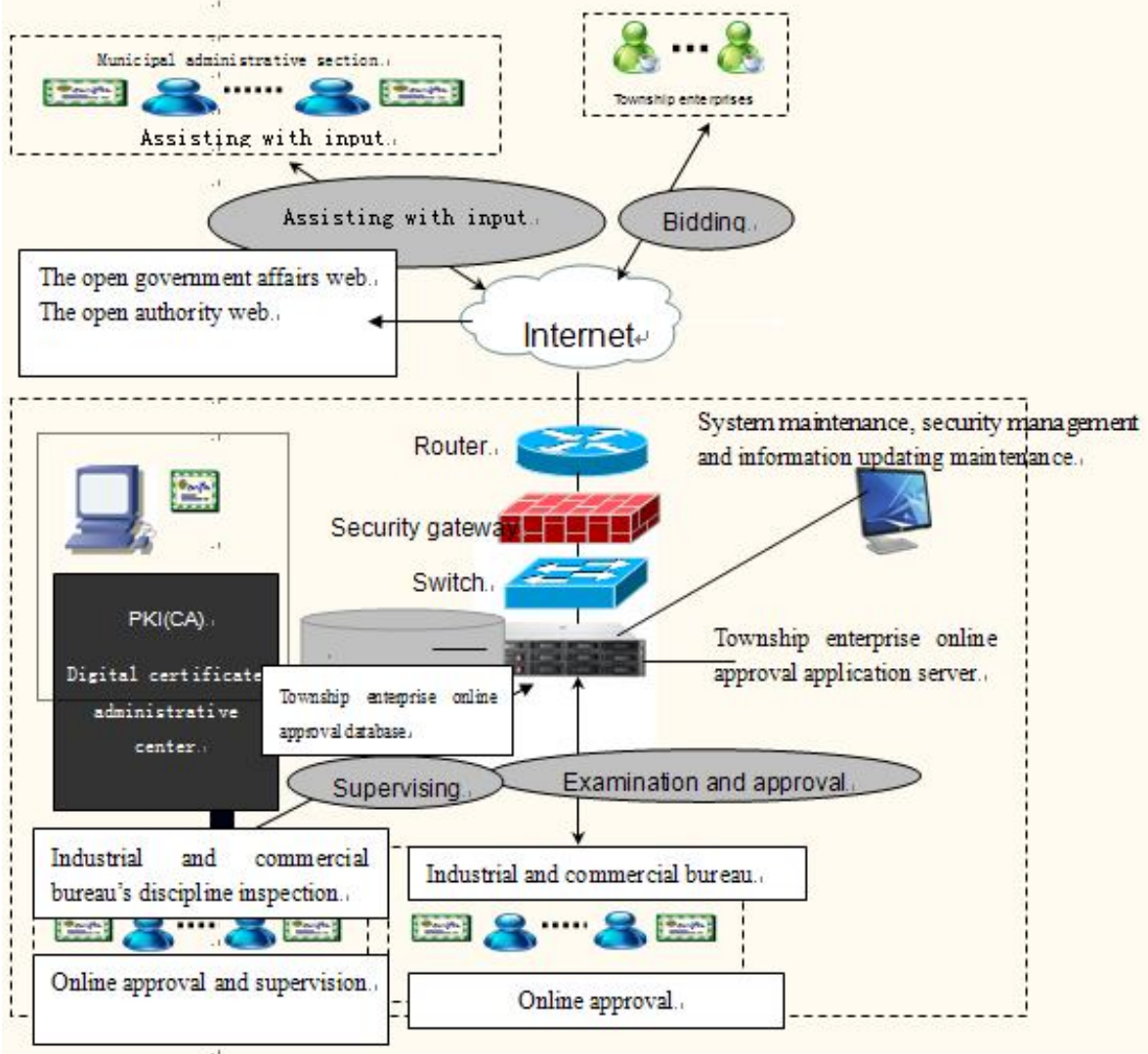

Fig. 1. The Overall Function Design of Township Enterprise Online Approval System 
for the interpretation and implementation of policies (referring to various kinds of national preferential policies and encouragement policies), calculating on numbers and examining and approving license for waste metal and coal marketing. The approval of township enterprises is handled by industrial and commercial bureau. If the enterprise is relatively large or with high technology content, the examination and approval shall be handled by development and reform bureau in the province, city and county first, and then get business license from industrial and commercial bureau.

\subsection{Requirements of Township Enterprise Online Approval Function}

\subsubsection{Online Approval Module}

The online approval business includes the record keeping of the founding of township enterprise and its business change. The online approval functional module consists of the declarer's bidding and inquiring function, assisting with input of villages and towns trade and economy commission and county township enterprises administrative bureau or industrial promotion bureau, industrial and commercial bureau's three-level approval function and industrial and commercial bureau's discipline inspection and supervision function. The online approval module, which is responsible for all the township enterprise approval business, is the core of township enterprise approval system. The necessary materials for township enterprises' founding include enterprise name, domicile, business place, legal representative or legal person, business registration number, economic nature, organization type, scope of business, mode of operation, category of business, registered capital, number of employees and duration of operation and so on. The required certifying documents shall be uploaded in the forms of scanning or be filled in Word document format.

It needs industrial and commercial bureau's three-level approval in the online approval module. The industrial and commercial bureau's three-level approval consists of preliminary reviewer's examination and verification, competent business director's examination and verification and competent business head's examination and approval. If any level of the three-level examination and approval system doesn't make any examination opinion, the examination and approval process will not continue. That is to say, the higher authority can only skim over the township enterprise' application information and can't make any specific examination and approval opinion if the lower authority doesn't express any opinion in accordance with the examination and approval process. The higher authority can make the decision of approval or not approval only when the low authority make the examination and approval opinion. This kind of process design can standardize the examination and approval process so as to avoid the skip-level examination and approval, which plays a significant role in the higher authority's supervision to the lower authority.

\subsubsection{Township Enterprise Information Management Module}

The township enterprise management module is responsible for collecting all the township enterprise information and managing the existing township enterprises. In this function module we can conduct such processes as certificate printing, information inquiry, township enterprise's cancellation of registration, generating and exporting of information, the management of township enterprise business registration number and so on. 


\subsection{Function Output of Township Enterprise Business Online Approval System}

Township Enterprise Business Online Approval System is composed of two sets of modules. One is Township Enterprise Approval System, including township enterprise set up approval system and township enterprise business change system; the other is Township Enterprise Database Management System, including inquiry system, report management system and certificate print system. Township Enterprise Online Approval System establishes relationships with terminal customers by relying on Internet. To ensure the safety of Township Enterprise Online Approval System and avoid attack and destruction of internet hackers, the system is divided into two web interfaces, one being logged in by natural persons and legal representatives who need transact township enterprise business through user name and password, another being used for approval of industrial and commercial bureau and assisting administrative department of township and county with inputting information through "dongle" password and user name and password. In addition, the system opens a discipline inspection and supervision window to make it easier to inspect and supervise so as to make the approval more transparent.

\subsubsection{Township Enterprise Approval System}

The applicant logs in the application web interface of the Township Enterprise Online Approval System and input user name, password and random verification code successively, according to the indication of the computer, to enter the online approval application program of township enterprise. Then the above mentioned user name and password belong to the applicant who shall remember them carefully for future login and inquiry of relevant information. According to the indication of the computer, the applicant reads the provisions regarding to the establishment application of township enterprise in the Regulations on Township Enterprise and Implementation Rules. After deeply understanding the required documents, conditions and document format for application, the applicant shall click "Next" to fill in the township enterprise establishment form item by item carefully. During the process of filling in the above form, if the applicant fills in wrong contents or the contents filled in need to be modified, then he can click command of modification to fill in the form again. After that, he scans and uploads supporting documents according to the required format. Finally he clicks "Save" and submit the form. The filling contents will be transmitted to Information Center server of Administration for Industry and Commerce through network.

The applicant, after receiving the documents returned from any approval level by industrial and commercial bureau, only needs to selectively modify the items not conforming to the provisions according to the suggestions. Then he can submit the documents and enter the approval link again. The purpose of adding the above function is to reduce the repeated input workload of the applicant and save application time.

\subsubsection{Township Enterprise Business Change System}

The business change of township enterprise refers to the change of investor, legal representative, business operation site as well as change of its name. If any above items change, the township enterprise shall go to the original approval authority in time to go through the formalities for the change of the relevant business. In order to facilitate the operators, the township enterprise business change function module is designed in the Township Enterprise Online Approval System. 
Changing applicant uses user name and password to log in the application web interface of the Township Enterprise Online Approval System and enter the Township Enterprise Online Business Change System. Then he shall, in accordance with the indication of the computer, fill in the business change application form of township enterprise after reading the application documents needed to be submitted for the change. During the process of filling in application form, if the alteration applicant fills in wrong contents or the contents filled in need to be modified, then he can modify the contents or fill in the application form again. After that, he scans and uploads supporting documents according to the required format. After the saving and submission, the filling contents will be transmitted to Information Center server of industrial and commercial bureau through network. The applicant of township enterprise shall remember the user name for login and inquiry of relevant information in the future.

The applicant for business change, after receiving the documents returned from any approval link by industrial and commercial bureau, only needs to selectively fill in the application form or modify the items not conforming to the provisions according to the suggestions. Then he can submit the documents and enter the business change link again.

\section{The Evaluation of Township Enterprise Online Approval System}

The application of Township Enterprise Online Approval System is a useful exploration and an attempt at using modern network technology to approve township enterprise. It is an important measure for standardizing township enterprise approval management, and it indicates a higher stage of approval management of township enterprise. Meanwhile it is also a useful attempt at promoting Township Enterprise Online Approval System all over the country.

\subsection{Convenient for Application}

The applicant can go through the application formalities of township enterprise at home through preparing the complete application documents in accordance with the requirements of Township Enterprise Registration and Record Stipulation.

\subsection{Convenient for Supervision and Making Approval Procedure Opener and More Transparent}

Every step and link of online checking and approval is recorded in files, thus it is convenient for inquiry and for the leaders to supervise and examine; discipline inspection and supervision window is specially set in the online approval system, it is convenient for discipline inspection and supervision and by doing this, it strengthens the openness of approval.

\subsection{More Standardized Approval Formality}

In the Township Enterprise Online Approval System, the traditional approval procedures and steps are edited into programs recognizable by the computer, the applicant 
only needs to submit step by step the necessary documents according to the conditions stipulated in the Township Enterprise Registration and Record Stipulation and the indication of the computer, then the industrial and commercial bureau can check and approve them step by step according to the programs of the computer, by doing this, it greatly reduces the human factors and non-standard operation in the traditional approval procedure.

\subsection{High Safety and Reliability of the Whole Approval System}

The applicant, using his user name and password, logs in the application web page to submit application documents, while the administration authorities at different levels $\log$ in the checking and approval web page with their keys and user names and passwords to check and approve the documents. The method of using different web pages for application and approval respectively effectively avoids the attack and destruction by network hackers and ensures the safety and reliability of the whole approval system.

\subsection{Greatly Improve Administrative Approval Efficiency}

The whole approval procedure, from the applicant's logging in the network to the checking and approval of administrative authority of township enterprise, is very simple and swift and it lasts no more than half a day. The whole process of application, checking and approval is open and transparent, favorable for building a clean and honest government.

\section{The Sphere of Application of Township Enterprise Online Approval System}

It is difficult for medium-and-small township enterprises to build a famous e-business platform since it needs supporting of technology and a large quantity of money. Township enterprise administrative authorities should build township enterprise private network and information sharing platform; construct a characteristic township enterprise information network system with sound system, fully functioning and highly practical and secure, which can make a link between the province, city, county, villages and towns and enterprises. And the network can also become a promoting platform to domestic and international market and in this way promote township enterprises e-business actively to intensification, economizing and efficiency.

\section{Conclusion}

The township enterprise online approval system belongs to the areas of e-government, and the main objective is to provide a convenient and effective way of doing business for the applicants. How to save the application time and cost of user and put forward a realistic model of the online approval system would be the basis for the township enterprises to transfer to the network. Using decomposition of structured analysis method step by step, the paper proposes a functional model of township enterprises 
online approval system. According to the characteristics of township enterprise business and combining with the traditional method of township enterprises business, the paper puts forward a kind of functional model of different functional modules and roles, which relies on the contacts between the internet network and end users. The functional model allows the user to shorten the application time to the minimum and satisfies the needs of users. It achieves standardization of township enterprise approval and management, thus reduces processing costs. It will also accept social supervision, so that the efficiency can be improved, and it serves the community better. In order to make the model functions well, it still needs to combine with the actual function of township enterprises approval, so that the function of the system can be further close to the actual environment.

\section{References}

1. Aharon, K.: Phases in the Rise of the Information Society. Info (2000)

2. General Office of the CPC Central Committee, General Office of the State Council: National Informationization Development Strategy 2006-2020. ZBF (2006), http://www.cnii.com.cn/20050801/ca350966.htm

3. Zhang, J.: Practical Exploration of Online Approval System. Journal of Ningbo Radio \& TV University (2007)

4. Zhang, J.: Design and Realization of Online Approval System. Journal of Lujiang University (2005) 